\title{
METHOD AND MEDIA USED IN TEACHING VOCABULARY AT TAMAN INDRIA IBU PAWIYATAN ACADEMIC YEAR 2012-2013 YOGYAKARTA
}

\author{
Tuti \\ STKIP Persada Khatulistiwa \\ tutiidris10@gmail.com
}

\begin{abstract}
Vocabulary is one of the essential elements in learning language. Survey data shows that students in kindergarten not easy to memorize new vocabulary. Therefore, researcher tries to analyze the method and media used by the teacher in teaching vocabulary. The objectives of the study are 1) to find out the methods and media that are used by the teacher in teaching vocabulary at Taman Indria Kindergarten. 2) to know the underlying reason of the teacher using those methods and media in teaching vocabulary.

The research approach is qualitative, with the research method used is descriptive. The study population was students of Taman Indria children age 3-5 years old the class consist of 20 students. The data were collected through observation, checklist, field note, video transcription and interview. The data were analyzed based on the characteristics of the methods which teacher applied in every activity. The results of the research showed that the teacher in Taman Indria mostly used Direct method and Total physical respond meanwhile, media that she used is whiteboard and picture.
\end{abstract}

Keywords: teacher; young learner; vocabulary; method; media

\section{INTRODUCTION}

Vocabulary is a foundation base for the language learner before they can speak or write into a sentence. In line with Hatch and Brown et.al (1995: 1). They say, "Vocabulary is the foundation to build languages, which plays a fundamental role in communication" in other words by mastering vocabulary; people are able to express their opinion or ideas. Students of kindergarten still study basic English. They study about simple words or things in their surroundings, it is aimed that students are able to understand simple words used in daily context. However, it is not easy to master the other competences without understanding the vocabulary, because vocabulary is the basic competence that must be reached by students in order to get other competencies like reading, writing, listening, and speaking. To learn vocabulary need a creative ways in order for the learner easy to learn and to comprehend.

Apart from this, the chosen of method and media becomes fundamental for teachers. Yet, the problems tend to face by teachers is uncreative in using method and media in teaching. They use monotonous media and method to teach the students. The 
data survey at Taman Indria, In 2013 showed that children still lack of vocabulary. It could be seen from two indicators: first, their vocabulary score was low. Second, the students did not have motivation during teaching-learning process.

Therefore, researchers are interested in seeing the method and media used by the teacher. Each teacher has different methods and media in teaching vocabulary. People cannot produce the words without having vocabulary. "Vocabulary is extremely important to convey the message for people around. Nunan (1991) reveals that Vocabulary is an important element in the acquisition of a second language. Nation, (1990) learner's previous experience is one of the burden and their mother tongue affect the amount of transfer that they can make from this to their present learning. The more regular and predictable the relationship between past and present learning, the greater the opportunity for transfer to occur, similarly. The more the teacher or the course designer draws attention to the similarities and patterns, the greater opportunity to transfer for this reason, knowledge of the learner's mother tongue and knowledge of the linguistic features of English are benefit to a teacher. Yet, without techniques and good methods the transfer of language also can be difficult (Cameron, 2002). Teaching words will be more easier if a teacher have some techniques and a set of classroom specifications for accomplishing linguistic objects (Richard and Rodgers 2001:18)

Many researchers have also found student has difficulty in learning vocabulary. There are many studies that show that students have difficulty in learning vocabulary. Therefore, to know methods and media in teaching vocabulary is important (Ur, 1998; Nation, 1990; and Cross 1991).

In this study methods and media used in teaching vocabulary. Where the questions are covering what are methods and media used by teacher. The purpose of the study is to find out methods and media for teaching and underlying reasons in applying those methods and media.

\section{METHOD}

\section{Time and research location}

This research was conducted in September 2012. The research was conducted in Taman Indria Yogyakarta. 


\section{Research subject}

Research subjects of this study are the first level students of Taman Indria Yogyakarta. The class consist of twelve students for class A and eight students for B class. The research was conducted in B class.

\section{Research data collection}

This datum were collected through observation and interview.

\section{Interviews}

The interview was conducted informally to the English teacher in Taman Indria. The writer interviewed the teacher by using the Indonesia language, so that the information was easy to be understood. In this case the data that writer got were used to support the writer observation result and also to find out the underlying reason of teacher using methods and media when she is teaching vocabulary.

\section{Observation}

The observation was done to see the teacher activity in the teaching-learning process. The writer observed the activity of teaching and learning process in Taman Indria kindergarten to know what methods and media which used by the teacher.

\section{Research instruments}

\section{Observation checklist}

The observation checklist enables the researcher got the data. The researcher could see the real situation in the classroom. In this study, the observation included the activities at the teaching-learning process in the classroom, the method and media used in teaching-learning vocabulary. Observation was used to answering the first and second problem formulation

\section{Field note}

Field note are written account of what the writer sees, hears, experiences, and thinks. It contains of teacher's talks, attitude, movement and also classroom activities. The writer jotted down every meeting during the observation.

\section{Audio and recording}


Audio and recording helps researcher keep the data. In this study, the researcher recorded all the interaction during the activity in the classroom, it is used to keep the data before transcript into written form.

\section{Data analysis technique}

a. Data reduction the research doing the data selection and then focus on the problems which want to analysis or make the category to make the correct interpretation

b. Data display is data is made in the form of text to the conclusion

c. Conclusion is done based on the data analysis through data reduction and displays.

The conclusion is the answer form the research problem.

\section{FINDING AND DISCUSSION}

Taman Indria has two classes for pupils aged 3-5 year olds, the class was divided into class A and B. Class A consisted of 13 students and for class B consisted of 8 students; only one teacher who was charge for English class in every meeting.

\section{Teaching media}

Table 1. Teaching media

\begin{tabular}{|l|l|l|l|l|l|l|l|}
\hline No & Media & \multicolumn{3}{|l|}{ Observation } & \multicolumn{3}{|l|}{ Total } \\
\cline { 3 - 8 } & & 1 & 2 & 3 & 4 & \\
\hline 1 & The teacher uses textbook & - & - & - & - & 0 \\
\hline 2 & The teacher writers on the white board & $\sqrt{ }$ & $\sqrt{ }$ & $\sqrt{ }$ & $\sqrt{ }$ & 4 \\
\hline 3 & The teacher uses cassette and speaker to listen to the song & - & - & - & - & 0 \\
\hline 4 & The teacher uses scrambled pictures & $\sqrt{ }$ & $\sqrt{ }$ & $\sqrt{ }$ & $\sqrt{ }$ & 4 \\
\hline 5 & The teacher uses flashcard & - & - & - & - & 0 \\
\hline 6 & The teacher uses photos & - & - & - & - & 0 \\
\hline 7 & The teacher uses puppet & - & - & - & - & 0 \\
\hline 8 & The teacher uses realia & - & - & - & - & 0 \\
\hline
\end{tabular}


A study was conducted to the teacher at Taman Indria Kindergarten. The purpose of the study was to discover the teaching media that are used for teaching students in learning English language. The table above showed that that in four meetings. She used white board and scrambled pictures as the media in teaching English.

\section{Teaching methods}

Table 2. Direct method

\begin{tabular}{|l|l|l|l|l|l|l|}
\hline No & Characteristics & \multicolumn{3}{|l|}{ Observation } & \multicolumn{2}{l|}{ Total } \\
\cline { 3 - 5 } & & 1 & 2 & 3 & 4 & \\
\hline 1 & Only everyday vocabulary and sentence were taught & $\sqrt{ }$ & $\sqrt{ }$ & $\sqrt{ }$ & $\sqrt{ }$ & 4 \\
\hline 2 & New teaching points were introduced orally & $\sqrt{ }$ & $\sqrt{ }$ & $\sqrt{ }$ & $\sqrt{ }$ & 4 \\
\hline 3 & $\begin{array}{l}\text { Concrete vocabulary was taught through demonstration } \\
\text { object, and pictures: abstract vocabulary was taught by } \\
\text { association of idea }\end{array}$ & $\sqrt{ }$ & $\sqrt{ }$ & $\sqrt{ }$ & $\sqrt{ }$ & 4 \\
\hline 4 & Correct pronunciation and grammar were emphasized & $\sqrt{ }$ & $\sqrt{ }$ & $\sqrt{ }$ & $\sqrt{ }$ & 4 \\
\hline
\end{tabular}

The table uses for direct method indicators to show what the teacher method tends to use. Overall, it can be seen that teacher applied direct method in her teaching activity.

Table 3. Suggestopedia

\begin{tabular}{|l|l|l|l|l|l|l|}
\hline \multirow{2}{*}{ No } & Characteristics & \multicolumn{3}{|l|}{ Observation } & \multirow{2}{*}{ Total } \\
\cline { 5 - 6 } & & 1 & 2 & 3 & 4 & \\
\hline 1 & The decoration, furniture, of the class is colorful & $\sqrt{ }$ & $\sqrt{ }$ & $\sqrt{ }$ & $\sqrt{ }$ & 4 \\
\hline 2 & Using music & $\sqrt{ }$ & $\sqrt{ }$ & $\sqrt{ }$ & $\sqrt{ }$ & 4 \\
\hline 3 & The class was controlled by teacher & $\sqrt{ }$ & $\sqrt{ }$ & $\sqrt{ }$ & $\sqrt{ }$ & 4 \\
\hline
\end{tabular}

The table indicated that the teacher used Suggestopedia method in her teaching and learning process and also the teacher decorates the classroom with colorful picture that stick on the wall. 


\section{Table 4. Silent way}

\begin{tabular}{|l|l|l|l|l|l|l|}
\hline No & Characteristics & \multicolumn{3}{|l|}{ Observation } & \multicolumn{2}{l|}{ Total } \\
\cline { 3 - 5 } & & 1 & 2 & 3 & 4 & \\
\hline 1 & $\begin{array}{l}\text { Learning is facilitated if the learner discoverers of creates } \\
\text { rather than remember and repeats what is to be learned }\end{array}$ & $\sqrt{ }$ & $\sqrt{ }$ & $\sqrt{ }$ & $\sqrt{ }$ & 4 \\
\hline 2 & $\begin{array}{l}\text { Learning is facilitated by accompanying (Mediating) } \\
\text { physical objects }\end{array}$ & $\sqrt{ }$ & $\sqrt{ }$ & $\sqrt{ }$ & $\sqrt{ }$ & 4 \\
\hline 3 & $\begin{array}{l}\text { Learning is facilitated by problem solving involving the } \\
\text { material to be learned }\end{array}$ & $\sqrt{ }$ & $\sqrt{ }$ & $\sqrt{ }$ & $\sqrt{ }$ & 4 \\
\hline
\end{tabular}

The table illustrates that teacher used silent way in teaching students in the classroom.

Table 5. TPR (Total Physical Response)

\begin{tabular}{|l|l|l|l|l|l|l|}
\hline No & Characteristics & \multicolumn{3}{|l|}{ Observation } & \multicolumn{2}{l|}{ Total } \\
\cline { 3 - 7 } & 1 & 2 & 3 & 4 & \\
\hline 1 & $\begin{array}{l}\text { The teacher speaks the language, usually in form of } \\
\text { command, while speaking s/he uses body movement to } \\
\text { help students understand the command }\end{array}$ & $\sqrt{ }$ & $\sqrt{ }$ & $\sqrt{ }$ & $\sqrt{ }$ & 4 \\
\hline 2 & $\begin{array}{l}\text { Students are asked to do/perform the activity/ies as stated } \\
\text { in the teacher utterances }\end{array}$ & $\sqrt{ }$ & $\sqrt{ }$ & $\sqrt{ }$ & $\sqrt{ }$ & 4 \\
\hline
\end{tabular}

The table shows that the teacher used total Physical Respond in four meeting.

\section{DISCUSSION}

This section presents the discussion based on the findings of the study. It is concerned about the media and methods that is used by the teacher in teaching English.

\section{Media that is used by the teacher}

Media are tools or physical things utilized by the teacher to spur the teaching process by applying a piece of authentic tool into the classroom. Hence, media is imperative in teaching and learning process. The finding of this study the teacher used white board and scrambled picture as media in teaching the students. 
This finding in line with Edith Manny-Ikan (2011), who found that understudies learning through White board are more mindful and have more prominent inspiration to learning. Also, Manny-Ikan pointed out that white board is a part of important media that must be considered by the teacher.

In spite of these positive reports on the advantage of the white board in teaching and learning process, other considers highlight that the increment in teaching engagement may as it were short-term. To preserve their level of engagement and their interest in learning, teaching through the white board must be more challenging than fair illustrating straightforward assignments on the board and has to create higher considering aptitudes among learners. Otherwise, there's a chance that the learners will desist to be interested over time, and the innovation will gotten to be obsolete and futile (Lancia, 2009). Additionally, within the current research, it is conceivable to see that nowdays, there was a slight diminish in students' positive demeanors relating to their crave to proceed learning through the white board.

It is conceivable that typically due to the more schedule utilize of the white board and the need for assortment in how the instructors or teachers use it. Such as, in arranging to preserve the high level of understudy inspiration, other strategies for using the white board got to be investigated. Considers that have inspected the relationship between the utilize of white board and learning accomplishment have found by some findings (Higgins et al., 2005; Lewis, 2003; Swan, Schenker, \& Kratcoski, 2008). Firstly, it appears that white board emphatically affected students' capacity to get it complex concepts, for case, in math and science ( Mildenhall, Swan, \& Marshall, 2008). Besides, scrambled pictures also can be one of alternative media for teaching kindergarten students.

\section{The methods that is used by the teacher}

The findings demonstrate that the teacher had made a difference in the understudies in teaching vocabulary by utilizing four methods. The findings are not parallel to the finding by Scarfo \& Littleford (2008), the play method made a difference the children to construct squares of information related to 'Weather' and progressed their vocabulary. The methods that were used by teacher need to be combined with playing activity, since we know that kindergarten students tend to play than study. Yet, if teacher can combine between studying and playing that will be better. 
As suggested by Nunan (1991), role play also can help children to participate actively in the learning process and enhances learning. These findings enable us to rethink that the use of the four methods has helped to arouse the children's interest in learning vocabulary. These findings validate earlier findings from the researchers conducted by Manny-Ikan (2011) that show when children are actively involved in the classroom their interest in the subject is enhanced. Furthermore, the total physical method is enables children to enjoy and have fun during the activities. Thus, pupils' interest in learning the subject increases and stimulates them in language learning.

\section{CONCLUSION}

To conclude, the used of media in kindergarten is still need creativity from teachers. The lack of media can cause slow learner in learning language. The more creative teacher the more students interest in learning. Hence, the findings of this study revealed that the teacher used the eclectic method and it contains in four characteristics of the method they are Total Physical Response, Direct method, Suggestopedia and silent way. Meanwhile media that she usually uses are picture and whiteboard the underlying reason were: to improve students motoric, to increase student's confidence, and to broaden students' knowledge and those methods is very useful in teaching kindergarten students.

\section{REFERENCES}

Cameron, L.2001. Teaching to Young Learner. Cambridge: Cambridge University Press. Cross, David. 1991. A Practical Handbook of Language Teaching. London: Cassel Hall, I., \& Higgins, S. (2005). Primary school students' perceptions of interactive whiteboards. Journal of Computer assisted learning, 21(2), 102-117.

Hatch, Evelyn and Brown, Cheryl. 1995. Vocabulary, Semantic, and Language Education. Cambridge: Cambridge University Press.

Lacina, J. (2009). Technology in the classroom interactive whiteboards: Creating higher-level, technological thinkers?. Childhood Education, 85(4), 270-272.

Lewis, H. (2003). Using an interactive whiteboard in the daily mathematics lesson: Implications for teaching and learning. UWIC Education Papers, 2, 41-52. 
Manny-Ikan, E., Dagan, O., Tikochinski, T., \& Zorman, R. (2011). Using the Interactive White Board in Teaching and Learning-An Evaluation of the SMART CLASSROOM Pilot Project. Interdisciplinary Journal of E-Learning and Learning Objects, 7(1), 249-273.

Mildenhall, P., Swan, P., Northcote, M., \& Marshall, L. (2008). Virtual manipulatives on the interactive whiteboard: A preliminary investigation. Australian Mathematics Teacher 64(1), 914.

Nation, ISP. 1990. Teaching and Learning Vocabulary. New York: Newbury House Publishers.

Nunan, D 1991. Language Teaching Methodology. London: Printice hall, inc.

Read, J. 2000. Assessing Vocabulary. Cambridge: Cambridge University Press.

Richard. J.C and Rodgers T. S 2001. Approach and Methods in Language Teaching. Universities of Hawai.

Scarfo C. \& Littleford J. (2008). It's Child's

http://www.etfo.ca/Publications/Voice/Voice\%20Back\%20Issues/Documents/February $\% 202008 /$ child's\%20play.pdf. Retrieved 5 January 2011.

Schmitt, N. 2000. Vocabulary in Language Teaching. Cambridge: Cambridge University Press.

Scoot T. 2002. How to teach Vocabulary. England: Pearson Longman.

Swan, K., Schenker, J., \& Kratcoski, A. (2008).The effects of the use of interactive whiteboards on student achievement. Proceedings of World Conference on Educational Multimedia, Hypermedia and Telecommunications 2008 (pp. 3290-3297). Chesapeake, VA: AACE.

Ur, Penny. 1998. A Course in Language Teaching: Practice and Theory. Cambridge: Cambridge University Press. 